\title{
Pengembangan Media Pembelajaran Monopoli pada Tema Ekosistem untuk Siswa Sekolah Dasar
}

\author{
Risma ${ }^{1}$, Agustinus Toding Bua ${ }^{2}$, Kartini $^{3}$, Muhsina Annisa ${ }^{4}$ \\ SD Negeri 007 Nunukan \\ E-mail: rismaima1307@gmail.com
}

\begin{abstract}
Abstrak
Tujuan penelitian ini adalah untuk mendeskripsikan kelayakan media pembelajaran monopoli ditinjau dari validasi ahli materi, media, bahasa, dan praktisi serta respon guru dan respon siswa. Jenis penelitian yang digunakan adalah penelitian pengembangan (Research and Development). Model pengembangan media yang digunakan oleh peneliti yaitu model perangkat 4-D modifikasi yang dilakukan hanya sampai 3-D yang terdiri dari Define, Design, dan Develop. Media pembelajaran yang dikembangkan oleh peneliti berupa media monopoli. Teknik Pengumpulan data yang digunakan adalah wawancara, observasi, kuesioner atau angket, dan dokumentasi. Hasil penelitian ini menghasilkan media pembelajaran Monopoli pada tematik tema 5 Ekosistem sub tema 2 hubungan antar makhluk hidup dalam ekosistem ditinjau dari validasi ahli, ahli media, ahli materi, ahli bahasa dan praktisi serta ditinjau dari respon guru dan respon siswa. Media pembelajaran monopoli termasuk dalam kriteria sangat layak. Hal ini berdasarkan dari keseluruhan validasi ahli dengan presentase $82 \%$, respon guru $86 \%$, dan respon siswa $98 \%$.
\end{abstract}

Kata Kunci: Media Pembelajaran, Monopoli, Ekosistem

\section{PENDAHULUAN}

Pendidikan merupakan salah satu aspek penting yang membantu dalam meningkatkan kualitas sumber daya manusia (SDM) untuk memajukan bangsanya dan mampu bersaing dengan negara lain. Berdasarkan Undang-undang nomor 20 tahun 2003 tentang sistem pendidikan nasional pasal 3, mengemukakan bahwa pendidikan nasional berfungsi mengembangkan dan membentuk watak serta peradaban bangsa yang bermartabat dalam rangka mencerdaskan kehidupan bangsa, bertujuan untuk mengembangkan potensi peserta didik agar menjadi manusia yang beriman dan bertakwa kepada Tuhan Yang Maha Esa, berakhlak mulia, sehat, berilmu, cakap, kreatif, mandiri, dan menjadi warga negara yang demokratis, serta bertanggung jawab.

Hal tersebut dapat didukung oleh adanya kurikulum. Di dalam Undang-Undang Republik Indonesia Nomor 20 Tahun 2003 tentang sistem pendidikan Nasional pasal 1 ayat 19, mengemukakan bahwa kurikulum adalah seperangkat rencana dan pengaturan mengenai tujuan, isi, dan bahan pelajaran serta cara yang digunakan sebagai pedoman penyelenggaraan kegiatan pembelajaran untuk mencapai tujuan pendidikan.

Berdasarkan undang-undang tersebut dapat disimpulkan bahwa kurikulum merupakan pedoman dalam merancang kegiatan pembelajaran. Kurikulum yang diterapkan di Indonesia adalah kurikulum 2013, akan tetapi sebagian besar sekolah di 
Indonesia sudah menerapkan kurikulum 2013. Menurut Shafa (2014) mengatakan bahwa kurikulum 2013 adalah kurikulum dengan karakter tujuan atau kompetensi lulusan yang dikemas dalam bentuk integrasi yang menekankan pada pendidikan karakter, karakter pembelajaran pada pendekatan saintifik dan karakter penilaian proses.

Menurut Akbar dalam Santu (2017:2) mengatakan bahwa pembelajaran yang kreatif, inovatif, dan efektif dapat tercapai apabila pendidik mampu memanfaatkan sumber dan media pembelajaran sesuai dengan tuntutan kurikulumnya. Penggunaan media pembelajaran yang berfungsi sebagai alat penyambung atau perantara dalam menyampaikan pesan-pesan terkait materi pelajaran yang akan disampaikan oleh guru. Hal ini sejalan dengan menurut Priatmoko dan Saptorini dalam Irawan (2017:2) mengatakan bahwa media pembelajaran adalah alat bantu yang bermanfaat dalam proses pembelajaran. Dengan menggunakan alat bantu, akan lebih memudahkan guru dalam menyampaikan materi pembelajaran.

Berdasarkan hasil wawancara guru dan angket gaya belajar siswa di kelas V-B yang telah dilakukan oleh peneliti di SDN 007 Nunukan, menunjukkan bahwa guru mengalami kendala dalam menggunakan media pembelajaran. Hal tersebut terjadi karena keterbatasan media yang disediakan oleh sekolah, adapun sebagian media yang rusak dan kurangnya pengembangan media yang dilakukan oleh guru dikarenakan biaya. Sehingga peserta didik merasa bosan dan kurang aktif dalam mengikuti proses pembelajaran yang kurang efektif dan kurang menyenangkan. Hasil angket gaya belajar yang diperoleh $66, \%$ peserta didik yang menyukai gaya belajar kinestetik, $63,7 \%$ peserta didik yang menyukai gaya belajar visual, dan $50,9 \%$ peserta didik yang menyukai gaya belajar audio.

Berdasarkan permasalahan tersebut, salah satu langkah yang dapat dilakukan guru adalah dengan melakukan pengembangan media pembelajaran. Pembelajaran dengan konsep belajar sambil bermain. Belajar sambal bermain dapat dilakukan melalui pengembangan media monopoli. Monopoli merupakan permainan yang dapat dimainkan oleh dua sampai lima peserta didik. Menurut Sadiman dalam Sartikaningrum (2013:6) mengatakan bahwa media pembelajaran monopoli dilakukan karena memiliki enam keunggulan yaitu (1) permainan adalah sesuatu yang menyenangkan untuk dilakukan, sesuatu yang menghibur, (2) permainan memungkinkan adanya partisipasi aktif dari siswa untuk belajar, (3) permainan dapat memberikan umpan balik langsung, (4) permainan memungkinkan penerapan konsepkonsep ataupun peran-peran ke dalam situasi dan peranan yang sebenarnya di masyarakat, 
(5) permainan bersifat menarik, (6) permainan dapat dengan mudah dibuat dan diperbanyak.

Belajar sambil bermain dengan menggunakan media pembelajaran monopoli dapat meningkatkan motivasi belajar siswa. Hal ini sejalan dengan Anggraheni (2018) dengan judul Pengembangan Media Permainan Monopoli Merah-Putih Pada Pembelajaran Tematik Integratif Peserta Didik Kelas V SD/MI Tahun Ajaran 2017/2018.

Berdasarkan uraian yang telah dijelaskan, perlu dilakukan pengembangan media pembelajaran monopoli kelas $\mathrm{V}$ tema 5 sub tema 2 hubungan antar makhluk hidup dalam ekosistem pembelajaran 6.

\section{METODE}

Peneliti menggunakan metode penelitian pengembangan yang sering dikenal dengan Research and Development $(R \& D)$ atau penelitian dan pengembangan dalam penelitian ini. Penelitian dan pengembangan (Research and Development) adalah jenis penelitian yang digunakan dalam pengembangan produk dan menguji keefektifan produk tersebut. Sedangkan menurut Sukmadinata dalam Sandra (2014:421) mengatakan bahwa penelitian dan pengembangan merupakan proses untuk mengembangkan suatu produk baru atau menyempurnakan produk yang telah ada dan dapat dipertanggung jawabkan. Penelitian pengembangan juga bertujuan untuk media yang layak dan tepat digunakan untuk meningkatkan proses dan hasil belajar siswa (Octaviana, Madyoeosusilo, \& Subiyantoro, 2018). Penelitian pengembangan ini memfokuskan pada pengembangan media pembelajaran monopoli.

Model pengembangan media monopoli pada penelitian ini mengacu pada model pengembangan 4D. Menurut Thiagarajan dalam Firdaus dkk (2015:2) mengatakan bahwa model 4-D terdiri dari empat tahapan penelitian yaitu; (1) pendefinisian (define), (2) perancangan (design), (3) pengembangan (develop), (4) penyebaran (disseminate). Namun pada penelitian ini dikarenakan keterbatasan waktu dan biaya, sehingga penelitian ini dapat dilakukan sampai tahap ke-3 yang terdiri dari (1) pendefinisian (define), (2) perancangan (design), pengembangan (develop). Penelitian ini dilakukan untuk menghasilkan suatu media pembelajaran monopoli yang dapat membantu memudahkan guru dan peserta didik dalam proses belajar mengajar.

Media yang dikembangkan berupa media monopoli. Uji coba media dilakukan sebagai dasar untuk mendeskripsikan kelayakan dari pengembangan media pembelajaran monopoli pada tema 5 ekosistem sub tema 2 hubungan antar makhluk hidup dalam ekosistem kelas V-B SD Negeri 007 Nunukan, semester ganjil tahun 2018-2019, subjek penelitian melibatkan 27 peserta didik. 
Penelitian ini dimaksudkan untuk menghasilkan suatu mediat pembelajaran yang Penelitian ini dilakukan di SDN 007 Nunukan yang beralamat Jl. TVRI, Kecamatan Nunukan Tengah. Pemilihan sekolah ini didasarkan pada hasil observasi awal dan hasil wawancara dengan guru kelas V-B di sekolah tersebut. Penelitian ini dilaksanakan pada bulan Maret 2019.

Teknik pengumpulan data dalam penelitian ini, yaitu wawancara, dokumentasi, lembar validasi, dan angket mengenai pengembangan media pembelajaran monopoli pada tema 5 ekosistem sub tema 2 hubungan antar makhluk hidup dalam ekosistem kelas V-B SDN 007 Nunukan.

Instrumen dalam penelitian ini terdiri dari lembar validasi media pembelajaran monopoli dan lembar respon peserta didik. Teknik analisis kelayakan perangkat pembelajaran meliputi analisis validasi ahli materi, konstruk, desain, bahasa dan praktis untuk media monopoli. Analisis data yang digunakan yaitu analisis deskriptif kuantitatif, selanjutnya dijabarkan dengan menggunakan analisis deskriptif kualitatif untuk. Teknik analisis data dalam penelitian ini, yaitu analisis kelayakan media monopoli dari hasil penilaian dosen ahli (materi, media, bahasa, dan praktisi), dan analisis respon guru dan siswa.

Penilaian disusun dengan skala Likert interval 1 sampai dengan 5 untuk menghitung dapat membantu memudahkan guru dan siswa dalam proses belajar mengajar.

skor rata-rata setiap butir pertanyaan, kemudian menghitung rata-rata skor keseluruhan dengan pedoman penskoran menggunakan rumus yang dikemukakan kementerian oleh Sugiyono dalam Angraheni (2018:53), dan selanjutnya mencocokkan persentase dan kriteria kelayakan media monopoli. Media pembelajaran monopoli dikatakan layak apabila nilai rata-rata kelayakan nya minimal berada pada kategori layak yaitu 61\%-80\%. Pedoman penskoran sebagai berikut:

Tabel 3.1 Pedoman Skor Penilaian Media Monopoli

\begin{tabular}{cll}
\hline Kriteria & Keterangan & Skor \\
\hline SL & Sangat Layak & 5 \\
L & Layak & 4 \\
CL & Cukup Layak & 3 \\
KL & Kurang Layak & 2 \\
TL & Tidak Layak & 1 \\
\hline
\end{tabular}

Penghitungan dengan menggunakan rumus, sebagai berikut.

$\mathrm{P}=\frac{\text { Jumlah Skor havil pengumpulan data }}{\text { Jumlah venwa ahor hriteria tertinggi }} \mathrm{X} 100$

Keterangan:

$\mathrm{P}=$ Persentase Kelayakan

Menyimpulkan hasil perhitungan dengan melihat tabel di bawah ini:

Tabel 3.2 Persentase dan Kriteria Kuantitatif Validasi

\begin{tabular}{cl}
\hline Persentase \% & Kriteria \\
\hline $\mathrm{P}^{>} 80 \%$ & Sangat layak \\
$60 \%{ }_{\mathrm{P} \leq 80 \%}$ & Layak \\
$40 \%{ }_{\mathrm{P} \leq 60 \%}$ & Cukup layak \\
$20 \%{ }_{\mathrm{P}} \leq 40 \%$ & Kurang layak \\
$\mathrm{P} \leq 20 \%$ & Tidak layak \\
\hline (Modifikasi dari Sugiyono dalam Angraheni, \\
\multicolumn{2}{c}{ 2018:52) }
\end{tabular}




\section{HASIL DAN PEMBAHASAN}

\section{Kelayakan Perangkat Pembelajaran}

Kelayakan media pembelajaran monopoli diukur berdasarkan hasil validasi ahli materi, media, bahasa, dan praktisi. Hasil analisis skor validasi perangkat pembelajaran secara keseluruhan ditunjukkan pada tabel 4.1 Berikut:

Tabel 4.1 Hasil Analisis Skor Validasi Media Monopoli

\begin{tabular}{|c|c|c|c|}
\hline No & Validator & $\begin{array}{c}\text { Skor } \\
\text { Validasi }\end{array}$ & Kriteria \\
\hline 1 & V1 & $73 \%$ & Layak \\
\hline 2 & $\mathrm{~V} 2$ & $88 \%$ & Sangat Layak \\
\hline 3 & V3 & $86 \%$ & Sangat Layak \\
\hline 4 & V4 & $81 \%$ & Sangat Layak \\
\hline \multicolumn{2}{|c|}{ Persentase } & $82 \%$ & $\begin{array}{l}\text { Sangat } \\
\text { Layak }\end{array}$ \\
\hline
\end{tabular}

\section{Keterangan: V1= Validator 1}

\section{V2= Validator 2, dan seterusnya.}

Tabel 4.1 menunjukkan bahwa hasil rata-rata skor secara keseluruhan dari keempat validator media pembelajaran monopoli memperoleh persentase $82 \%$ dengan kriteria sangat baik. Berdasarkan hasil analisis tersebut dapat disimpulkan bahwa pengembangan media pembelajaran monopoli pada tema 5 ekosistem sub tema 2 hubungan antar makhlik hidup dalam ekosistem di Kelas V-B SD Negeri 007 Nunukan ditinjau dari hasil uji validasi materi, media, bahasa dan praktisi secara keseluruhan menunjukkan persentase sebesar $82 \%$ dengan kriteria sangat layak digunakan dalam pembelajaran di sekolah.

\section{Uji Coba Terbatas}

Pada tahap ini peneliti melaksanakan penelitian selama satu hari pada tanggal 4 maret 2019. Uji coba media pembelajaran monopoli dilakukan oleh 10 peserta didik dilakukan di kelas V-D SDN 007 Nunukan. Peserta didik yang dipilih adalah peserta didik yang telah menerima pelajaran tema 5 ekosistem sub tema 2. Dalam uji coba terbatas diperoleh data tentang respon siswa. Hasil uji coba digunakan untuk merevisi media pembelajaran monopoli (draft II) dan menghasilkan draft III media pembelajaran monopoli menunjukkan bahwa persentase yang diperoleh adalah 98,5\% dan berada pada kriteria sangat baik. Berdasarkan hasil uji coba terbatas, siswa juga memberikan komentar dan saran pada angket respon siswa yang diberikan setelah memainkan media monopoli.

\section{Analisis Respon Guru}

Hasil pengamatan respon guru selama kegiatan pembelajaran dengan menggunakan media permainan monopoli pada pembelajaran 6 disajikan secara singkat pada tabel 4.2. 
Tabel 4.2 Analisis Respon Guru

\begin{tabular}{|c|c|c|c|}
\hline No. & Butir Penilaian & Skor Validasi & Kriteria \\
\hline 1 & $\begin{array}{l}\text { Media monopoli potensial menunjang } \\
\text { ketercapaian tujuan pembelajaran }\end{array}$ & 5 & Sangat Layak \\
\hline 2 & $\begin{array}{l}\text { Petunjuk penggunaan media monopoli mudah } \\
\text { dipahami }\end{array}$ & 4 & Layak \\
\hline 3 & $\begin{array}{l}\text { Media monopoli membuat siswa terlihat aktif } \\
\text { dalam pembelajaran }\end{array}$ & 5 & Sangat Layak \\
\hline 4 & Media monopoli mudah digunakan siswa & 4 & Layak \\
\hline 5 & Media monopoli dapat membuat siswa antusias & 5 & Sangat Layak \\
\hline 6 & $\begin{array}{l}\text { Konsep, gambar dan informasi yang terdapat } \\
\text { pada media monopoli }\end{array}$ & 4 & Layak \\
\hline 7 & Media monopoli menarik & 4 & Layak \\
\hline 8 & $\begin{array}{l}\text { Teks yang digunakan komutatif dan interaktif } \\
\text { sesuai dengan karakteristik siswa }\end{array}$ & 5 & Sangat Layak \\
\hline 9 & $\begin{array}{l}\text { Gambar pada media pembelajaran monopoli } \\
\text { menarik }\end{array}$ & 4 & Layak \\
\hline 10 & $\begin{array}{l}\text { Jenis, warna dan ukuran huruf yang digunakan } \\
\text { sesuai dengan siswa }\end{array}$ & 4 & Layak \\
\hline 11 & $\begin{array}{l}\text { Penggunaan bahasa, ejaan dan tanda baca sesuai } \\
\text { dengan kaidah yang benar }\end{array}$ & 4 & Layak \\
\hline 12 & $\begin{array}{l}\text { Penggunaan media pembelajaran monopoli } \\
\text { dapat membuat siswa antusias }\end{array}$ & 4 & Layak \\
\hline 13 & $\begin{array}{l}\text { Media monopoli sudah sesuai sebagai media } \\
\text { penunjang selain buku pelajaran }\end{array}$ & 4 & Layak \\
\hline \multicolumn{2}{|c|}{ Jumlah Skor } & 56 & Sangat Layak \\
\hline \multicolumn{2}{|c|}{ Persentase } & $86 \%$ & Sangat Layak \\
\hline
\end{tabular}

Berdasarkan tabel 4.2 menunjukkan bahwa persentase yang diperoleh adalah $86 \%$ dan berada pada kriteria sangat baik. Dengan demikian, aktivitas peserta didik menggunakan media pembelajaran monopoli telah memenuhi kriteria sangat baik.

\section{Hasil dan analisis respon siswa}

Respon siswa terhadap pembelajaran dengan menggunakan media pembelajaran monopoli diperoleh dengan menggunakan angket respon siswa dan diberikan setelah berakhirnya kegiatan proses belajar mengajar pada tema 5 sub tema 2 pembelajaran 6 menunjukkan bahwa persentase keseluruhan sebesar $98 \%$ dengan kriteria sangat baik. Jadi disimpulkan bahwa media pembelajaran monopoli sangat efektif digunakan dalam proses belajar mengajar.
Setelah dilakukan analisis terhadap penilaian media pembelajaran monopoli oleh para ahli. Penilaian disusun dengan skala Likert Interval 1 sampai dengan 5 untuk menghitung skor rata-rata setiap butir pertanyaan, kemudian menghitung rata-rata skor keseluruhan dengan pedoman penskoran menggunakan rumus yang dikemukakan oleh Sugiyono dalam Angraheni (2018:53), dan selanjutnta mencocokkan persentase dan kriteria kelayakan media monopoli. Media pembelajaran monopoli dikatakan layak apabila nilai rata-rata kelayakannya minimal berada pada kategori layak yaitu 61\%-80\%.

\section{Validasi Ahli Materi}

Penilaian validasi ahli materi media pembelajaran monopoli dengan perolehan skor 5 menyatakan bahwa bahasa soal yang mudah dipahami dan kejelasan petunjuk belajar, 
peroleh skor 4 menyatakan bahwa kesesuaian materi dengan $\mathrm{KI}$ dan $\mathrm{KD}$, kesesuaian materi dengan indicator, kesesuaian materi dengan tujuan pembelajaran, dan kedalaman soal sesuai materi, peroleh skor 3 menyatakan bahwa kesesuaian materi dengan contoh soal, media monopoli dapat membuat siswa antusias, kelengkapan cakupan soal, tingkat kesulitan soal sesuai materi, variasi bentuk soal, dan ketepatan kunci jawaban dengan soal. Hasil validasi materi media pembelajaran monopoli memperoleh jumlah skor sebesar 44 dengan persentase $73 \%$ berada pada kriteria layak.

\section{Validasi Ahli Media}

Penilaian validasi ahli media pembelajaran monopoli dengan perolehan skor 5 menyatakan bahwa kesesuaian penggunaan ukuran font huruf, ketepatan perpaduan warna dalam monopoli, tata letak gambar menarik, kejelasan gambar yang digunakan, kelengkapan keterangan gambar, media monopoli mudah digunakan siswa, media monopoli kuat, tahan lama dan dapat digunakan berkali-kali, media monopoli dapat membuat siswa antusias, memperoleh skor 4 menyatakan bahwa ukuran monopoli proporsional, tampilan fisik monopoli menarik, ketepatan penggunaan jenis font huruf, keseuaian gambar dengan materi terkait, ketepatan penggunaan gambar dalam membantu pemahaman siswa, media monopoli memfasilitasi siswa aktif dalam pembelajaran, petunjuk penggunaan media monopoli mudah dipahami siswa, media monopoli sudah sesuai sebagai penunjang selain buku pelajaran, media monopoli sesuai dengan karakteristik siswa kelas V, dan media monopoli dapat membantu siswa memahami materi. Hasil validasi materi media pembelajaran monopoli memperoleh jumlah skor sebesar 80 dengan persentase $88 \%$ berada pada kriteria sangat layak.

\section{Validasi Ahli Bahasa}

Penilaian validasi ahli bahasa media pembelajaran monopoli dengan perolehan skor 5 menyatakan bahwa bahasa yang digunakan lugas dan mudah dipahami oleh siswa, bahasa yang digunakan sudah komutatif, dan bahasa soal yang mudah dipahami, peroleh skor 4 menyatakan bahwa ketepatan pemilihan bahasa dalam menguraikan materi, istilahistilah yang digunakan tepat dan sesuai materi, kalimat yang dipakai mewakili isi informasi yang ingin disampaikan, petunjuk penggunaan media monopoli disampaikan dengan jelas, konsistensi penggunaan istilah, konsistensi penggunaan simbol atau ikon, dan ketepatan ejaan. Hasil validasi materi media pembelajaran monopoli memperoleh jumlah skor sebesar 43 dengan persentase $86 \%$ berada pada kriteria sangat layak.

\section{Validasi Praktisi}

Penilaian validasi praktisi media pembelajaran monopoli dengan perolehan skor 5 menyatakan bahwa media monopoli memuat petunjuk cara penggunaannya, media monopoli memfasilitasi siswa untuk terlibat aktif dalam pelajaran, media monopoli kuat, tahan lama dan dapat digunakan berkali-kali, media monopoli mudah dibawa, media monopoli indah dan menarik bagi siswa, pembelajaran menggunakan media monopoli dapat membuat siswa antusias, peroleh skor 4 menyatakan bahwa kesesuaian media monopoli dengan $\mathrm{KI}$ dan $\mathrm{KD}$, kesesuaian materi dengan indicator, media monopoli potensial menunjang ketercapaian tujuan pembelajaran, media monopoli mudah digunakan siswa, pemilihan warna pada media monopoli menarik, jenis dan ukuran huruf sesuai dan mudah dibaca, media monopoli tidak mengandung unsur salah konsep, teks mendukung penjelasan media monopoli dan mudah dipahami oleh siswa, bahasa komunikatif dan mudah dipahami, peroleh skor 3 menyatakan bahwa media monopoli sudah sesuai sebagai penunjang selain buku pelajaran, media monopoli sesuai dengan karakteristik siswa kelas v, ukuran pembuatan media monopoli proporsional, media monopoli dapat mempermudah siswa dalam memahami materi, keruntutan materi. Hasil validasi materi media pembelajaran monopoli memperoleh jumlah skor sebesar 81 dengan 
persentase $81 \%$ berada pada kriteria sangat layak.

\section{Penilaian Respon Guru}

Penilaian respon guru terhadap media pembelajaran monopoli dengan perolehan skor 5 menyatakan bahwa media monopoli potensial menunjang ketercapaian tujuan pembelajaran, media monopoli membuat siswa terlihat aktif dalam pembelajaran, media monopoli dapat membuat siswa antusias, dan teks yang digunakan komutatif dan interaktif sesuai dengan karakteristik siswa, peroleh skor 4 menyatakan bahwa petunjuk penggunaan media monopoli mudah dipahami, media monopoli mudah digunakan siswa, konsep, gambar dan informasi yang terdapat pada media monopoli, media monopoli menarik, gambar pada media pembelajaran monopoli menarik, jenis, warna dan ukuran huruf yang digunakan sesuai dengan siswa, penggunaan bahasa, ejaan dan tanda baca sesuai dengan kaidah yang benar, penggunaan media pembelajaran monopoli dapat membuat siswa antusias, dan media monopoli sudah sesuai sebagai media penunjang selain buku pelajaran. Hasil validasi materi media pembelajaran monopoli memperoleh jumlah skor sebesar 43 dengan persentase $86 \%$ berada pada kriteria sangat baik.

\section{Uji Coba Terbatas}

Uji coba terbatas ini dilakukan di kelas V-D SDN 007 Nunukan dengan 10 siswa. Hasil dari penilaian respon siswa yang didapatkan oleh peneliti adalah memperoleh persentase sebesar $98,5 \%$ berada pada kriteria sangat baik.

\section{Uji Coba Lapangan}

Uji coba terbatas ini dilakukan di kelas V-B SDN 007 Nunukan dengan 27 siswa.
Hasil dari penilaian respon siswa yang didapatkan oleh peneliti adalah memperoleh persentase sebesar $98 \%$ berada pada kriteria sangat baik.

\section{KESIMPULAN}

Berdasarkan penjelasan dari bab sebelumnya, maka dapat disimpulkan bahwa produk ini telah melalui beberapa uji validasi ahli dan uji coba produk, yaitu validasi materi, validasi media, validasi bahasa, praktisi, uji coba terbatas berjumlah 10 peseta didik, dan uji coba lapangan dengan respon guru kelas dan berjumlah 27 peserta didik. Berdasarkan hasil validasi ahli dan uji coba produk menunjukkan bahwa kualitas produk telah mencapai standar kelayakan media pembelajaran. Validasi ahli materi memperoleh hasil persentase rata-rata $73 \%$ dengan kriteria "layak". Validasi ahli media memperoleh hasil persentase rata-rata $88 \%$ dengan kriteria "sangat layak". Validasi ahli bahasa memperoleh hasil persentase rata-rata $86 \%$ dengan kriteria "sangat layak". Validasi praktisi memperoleh hasil persentase rata-rata 81\% dengan kriteria "sangat layak". Adapun uji coba terbatas memperoleh hasil persentase rata-rata 98,5\% dengan kriteria "sangat baik". uji coba lapangan dari respon guru memperoleh hasil persentase rata-rata $86 \%$ dengan kriteria "sangat layak" dan respon siswa memperoleh hasil persentase rata-rata 98\% dengan kriteria "sangat baik". Berdasarkan hasil uraian di atas maka produk yang dikembangkan yaitu media pembelajaran monopoli ekosistem dikatakan layak digunakan sebagai media pembelajaran di kelas V. 


\section{DAFTAR PUSTAKA}

Angraheni, Nilam Sri. 2018. Pengembangan Media Permainan Monopoli Merah-Putih Pada Pembelajaran Tematik Integratif Peserta Didik Kelas V SD/MI Tahun Ajaran 2017/2018. Universitas Islam Negeri.

Firdaus Zuhri. 2015. Pengembangan Media Pembelajaran Monopoli Ipa Materi Sistem Pencernaan Makanan Untuk Siswa Kelas VIII di SMP Negeri 4 Malang. Universitas Negeri Malang.

Irawan Dedek. 2017. Pengembangan Media Permainan (Game) Monopoli Pada Pembelajaran Fisika Materi Besaran Dan Satuan Pada Tingkat Sekolah Menengah Pertama (SMP). Universitas Islam Negeri Ar-Ran.

Octafiana, W., Ekosusilo, M., \& Subiyantoro, S. (2018). PENGEMBANGAN MULTIMEDIA INTERAKTIF PADA MATERI PESAWAT SEDERHANA UNTUK SISWA SEKOLAH
DASAR. Jurnal Komunikasi Pendidikan, 2(2), 168-175.

Sandra Lisa. 2014. Pengembangan Media Pembelajaran Permainan Monopoli Pada Pokok Materi Perkembangan Kerajaan Hindu-Buddha Di Indonesia Kelas XI-IPA 2 SMA Negeri 1 Driyorej. Universitas Negeri Surabaya.

Santu, Robertus Farman. 2017. Pengembangan Media Papan Penjumlahan Pada Materi Pokok Penjumlahan Dalam Subtema Gemar Berolahraga Untuk Siswa Kelas I Sekolah Dasar. Universitas Sanata Dharma.

Sartikaningrum, Ria. 2013. Pengembangan Media Pembelajaran Permainan Monopoli Akuntansi Untuk Meningkatkan Motivasi Belajar Siswa Kelas X Program Keahlian Akuntansi SMK Negeri 1 Tempel. Universitas Negeri Yogyakarta.

Shafa. 2014. Karakteristik Proses Pembelajaran Kurikulum 2013. Jurnal: Samarinda. 